\title{
EUROPEAN TERRITORIAL COOPERATION AS A FACTOR OF TOURISM DEVELOPMENT
}

\section{Stanislav Filip}

School of Economics and Management in Public Administration, Public Administration Institution, Bratislava, Slovak Republic

\section{L'ubica Filipova}

School of Economics and Management in Public Administration, Public Administration Institution, Bratislava, Slovak Republic

\section{Olena Rayevnyeva}

Simon Kuznets Kharkiv National University of Economics, Head of Statistics and Economic Forecasting Department, Kharkiv, Ukraine

\section{CMESTE}

JEL Category: H7, R1

\begin{abstract}
The article presents the outcome of qualitative and quantitative research methods applied by the authors to evaluate benefits and obstacles of the cross-border INTERREG program between Hungary and the Slovak Republic from 2014 to 2020, as one of the tools of European territorial cooperation for tourism development concerning bordering regions of Slovakia. This article aims to provide a recipient with a verified research method and results of the analysis to encourage more efficient employment of the European territorial cooperation to alleviate differences in bordering regions between the Slovak Republic and Hungary, furthermore with other non-member states of EU such as Serbia or Ukraine. Besides the most essential institutional and legal outputs of the topic in question, analysis, and evaluation of the current condition reflecting the tourism development in the Slovak Republic are provided. The quantitative analysis offers results of systems analysis regarding the direct, indirect, and induced contribution of tourism GDP creation and employment. World Tourism Organization Yearbooks were taken into account as the secondary sources to analyze the development of tourism in Slovakia in comparison with other European countries. Official statistics published by the Statistical Office of the Slovak Republic and the INTERREG cross-border cooperation program portal of Hungary and the Slovak Republic for 2014-2020 were the basis for analyzing and comparing the benefits of cross-border cooperation programs between Slovak republic and Hungary for the development of tourism including all three periods. Quantitative indicators such as

Address of the corresponding author: Stanislav Filip 麦=”' stanislav.filip@vsemvs.sk awareness of the local public authorities and legal persons involved, benefits, and obstacles within tourism programs were analyzed by primal sources
\end{abstract}


in the process of the statistical survey and verified by the Delphi method in the conclusion. The results of partial analyses and surveys served as the basis for drafts of measures to improve the current state of employment of cross-border cooperation programs for the development of tourism across the bordering area of Slovakia and Hungary.

Keywords: cross-cultural research/measurement issues, data analysis, data source: primary data source: secondary, economic growth, institutional environment, tourism development, European territorial cooperation, INTERREG Slovakia-Hungary

\section{INTRODUCTION}

Tourism is set to be one of the most dynamic economic sectors within the national and European regions. The argument supporting tourism as one of the top economical sectors in Slovakia reflects foreign exchange gain amount of 1.8 billion EUR during the last fruitful years. There are more than 20.000 economic operators active in the tourism industry, comprising approximately accommodation facilities with 122.000 beds. According to the Ministry of transport and construction of Slovak republic. (abbrev. MoTC SR). (Tourism, 2020.)

The tourism industry as a set of activities focusing on satisfying the needs of citizens regarding traveling is a cross-cutting sector of national with direct or indirect influence on processes in the industry, business, and services, finance, transport, regional development, culture, sports activities and protection of the environment. The tourism sector stimulates employment rates by the creation of vacant job positions. It is fair to say that tourism provides a unified aim covering various sectors to create establishments for active and passive national and international tourism.

Local and international investment are crucial economical tools of tourism in provision to Slovak republic since its accession to the European Union. (abbrev. EU).

Member states of the EU were permitted to draw on resources regarding tourism development in 2013 through European regional development fund.

Operational programs of the European territorial cooperation are the main resources of the European Union in tourism development in bordering regions of member states. The EU allocated more than $€ 500$ mil. EUR for the period 2014-2020, solely for programs cross-border cooperation operated under name INTERREG. More than 183 mil EUR has been designated by
EU to program of cross-border cooperation INTERREG V-A Slovakia - Hungary and more than 80 mils EUR to cross-border cooperation program Hungary - Slovakia - Romania Ukraine.

Contribution to the sustainable growth of GDP as well as other possibilities of EU financial support for the development of tourism in border regions was the main objective of a survey conducted by VŠEMVS in cooperation with the association „Združením miest a obcí Slovenskej Republiky“, with local government authorities, citizens and city mayors of particular bordering regions with Hungary.

Concluded results demonstrate the strengths and weak spots of the current state and provide various suggestions for improvement. Authors of the article use a verified method to inspire subsequent research on this issue in SR and other countries keen on accession to the EU, such as Serbia and Ukraine.

However, this paper deals with the contribution of tourism on GDP growth and employment rate only briefly authors focus mainly on analysis and evaluation of the current state of EU financial support regarding tourism development in bordering regions of Slovakia and Hungary.

\section{LITERATURE REVIEW}

Overall review focus on terminology and terms related to tourism and its effect on GDP and employment rate. The main aspect of the review is to specify the possibilities of EU financial support provided to member states for tourism development in border regions.

The overview applies data obtained from available domestic and foreign resources of scientific and professional literature, documents of relevant public administration institutions of the Slovak Republic, and international organizations, as well 
as international and national legal standards of the Slovak Republic.

In the publication Tourism. Politics and Economics (Gucik, Tourism. Politics and economy, 2011)Gucik describes tourism policy and tourism economics. Management of the tourist destination (Gucik \& al., 2012) introduces innovative knowledge to the issue for experts in the field who are concerned by the development of tourism at destinations in the Slovak Republic. The economic and social effects of tourism on government revenue for the state budget are characterized by Novacka (2011). Publication Tourism and the European Union provides a comprehensive view of the conditions and relations that are being formed, developed, and present within the European Union in the context of tourism. Palatkova (2011) presents a comprehensive view of international tourism in the book International Tourism.

Ministry of transport and construction of Slovak republic as the Central State Administration Body defines tourism as ,the set of leisure activities with scope to satisfy needs connected to traveling and motion of citizens outside of their permanent residence" (MoTC SR, 2020).

Several Hungarian experts have been dealing with the strategic issues of northern Hungary and regional research aimed at developing the tourism of the country. The relation between tourism and regional competitiveness through the example "Matrai Rural" is addressed by Bujdoso, Lorant, Herneczky, and Tóth (2007)

Cross-border cooperation is generally considered a specific area of bilateral and multilateral international relations of neighboring countries. However, currently, there is a lack of professional publications on cross-border cooperation.

Cross-border cooperation of two particular countries focuses on the development of cities and regions to detect and evaluate natural and regional characteristics of border areas, development of the transport infrastructure, ecotourism, agrotourism, attractivity of sightseeings, health care system concerning public accessibility, increase the number of education subjects providing lessons in the language of the minority, support partner schools, support cooperation among local and regional municipalities with a significant number of Slovak or Hungarian minority citizens (Agreement,2002).

Programm INTERREG has been an initiative of Union supported with a budget of 1 billion and in 1990 concerning solely cross-bordering cooperation.

Slovak republic, shortly after accession to the EU, was allowed to profit from the third cross-border cooperation program of Union Interreg III Slovak republic - Hungary - Ukraine 2004-2006 during the shortened programming period of three years.

From 2007 to 2013, the Slovak Republic could draw on financial support for cross-border cooperation under the revised European Territorial Cooperation Program. The Interreg IV Slovak Republic - Hungary program for 2007-2013 was approved for cooperation with the Republic of Hungary.

In the period 2014-2020, European territorial cooperation, alongside the Growth and Jobs objective, is one of the two objectives of EU Cohesion Policy. Over the years, INTERREG V has become a key instrument of the European Union to foster cooperation between partners from different countries. (Kovac, 2016); (Sidak, Cibak, \& Hajnisova, 2020)

The aim is to find mutual solutions for issues, whether in the fields of health, tourism, research and education, transport, or sustainable energy. INTERREG programs are financed from the European Regional Development Fund to support the harmonious development of the European Union territory at various levels.

The question of European and world-wide tourism is a matter of focus World Tourism organization (UN WTO), OCEDD, EU, and Visegrad group. World Travel and Tourism Council (WTTC) is a particular body to conduct research and evaluation process on travel and tourism impact globally.

UN WTO (2020) gathers statistical data on tourism in member states under Tourism Satellite Account (TSA) to support unified system with aiming to foster knowledge in a particular sector, monitor progress, evaluate the impact of promotion on tourism results. The Yearbook of Tourism Statistics is published annually with the latest edition of the Yearbook published in 2020 for the 
years 2014 to 2018 and containing data from 197 countries. (UN WTO, 2017).

Tourism and cross-border development issues are reflected in the work by Stoffelen and Vanneste, (2017). Stoffelen, loannides, and Vanneste (2017) dealt with the obstacles to cross-border tourism management on the example of the CzechGerman border region. Opportunities for crossborder entrepreneurship development in a cluster model exemplified by the Polish-Czech border region were the topic of Polish authors Kurowska, Pysz, (2016). The authors contributed to the research of presentation issues and the case study Implementation of sustainable tourism in the German Alps (Paunovic \& Jovanovic, 2017).

\section{AIMS}

Based on the current state of knowledge of the problem in question, the main aim of the research was analysis and evaluation of the results of objective (financial and non-financial) indicators of the impact of INTERREG programs within the European Territorial Cooperation on tourism development.

Data collected in statistical survey help to assess subjectively, perceived assessment indicators of the impact of the current state of use on crossborder cooperation within tourism development in the bordering region of the Banská Bystrica region and the adjoining Hungarian region, identification and evaluation of benefits and obstacles to tourism development in this region. The following partial tasks have been set assessment to accomplish this aim:

- Elaborate an overview of examined issues based on data from local and foreign resources.

- Analyze a contribution of Slovak tourism on economic growth during the last two programming periods 2007-2018 with a prospect in 2027.

- Analyze and compare funding of cross-border cooperation projects in tourism within the Cross-border Cooperation Program of the Slovak Republic and Hungary in the programming periods 2004 - 2006, 2007 2013 and $2014-2020$

- Integrate a statistical survey to determine the state of public satisfaction and awareness on the possibilities and acknowledged benefits and obstacles of using the SR-HR Cross-Border Cooperation Programs for 2014-2020 in the area of tourism in the border area of Slovakia and Hungary

- Integrate a statistical survey to determine the state of satisfaction and awareness among mayors of cities in the Nohohrad region the possibilities to apply outputs of the Cross-Border Cooperation Programme between SR and Hungary on the development of tourism and detect benefits and obstacles.

- Using the Delphi expert method to verify the research results with an emphasis on the current barriers to the use of the Slovakia - Hungary cross - border cooperation program for the development of tourism.

\section{RESEARCH METHODOLOGY}

The research target problem was to determine the share of cross-border cooperation programs in tourism development using analyzes of objective and subjective indicators. The research was based on statistical data of the World Council of Tourism and Tourism WTTC, the Statistical Office of the SR, the Ministry of Agriculture and Rural Development of the SR and the Ministry of Transport and Construction of the SR and statistical survey of particular indicators of crossborder cooperation for tourism development conducted among employees of municipalities, mayors, inhabitants of the border area of Slovakia and Hungary, entrepreneurs and experts in crossborder cooperation.

One main and seven specific hypotheses were presented to verify the research target problem.

Main hypothesis $(\mathrm{MH})$ : Cross-border cooperation program between Slovakia and Hungary in the period of 2014-2017 is a determinative aspect of development and tourism in neighboring regions of Slovakia and Hungary.

Specific hypotheses were confirmed by citizens, mayors, and experts in tourism and cross-border cooperation.

The main target of qualitative research, i.e. objective indicators of impact was: 
- The overall contribution of tourism on Slovak GDP

- Contribution of tourism on the employment rate in Slovakia

- Ranking position of Slovakia in previously mentioned indicators in as compared on a global scale or with particular member states of EU including Hungary, Serbia, and Ukraine The main target of qualitative research i.e. objective indicators of impact was:

- public awareness on the importance, benefits, and obstacles of cross-border cooperation programs between Hungary and Slovakia on tourism development.

- acknowledgment of city mayors and other municipality authorities on the importance of cross-border cooperation programs between Hungary and Slovakia on tourism development and their perception of benefits and obstacles of such program.

- the consensus among experts regarding project draft and implementation to boost tourism on cross-border cooperation programs between Hungary and Slovakia on tourism development

The primary research data were obtained by mathematical-statistical analysis of publicly available databases of the World Tourism and Tourism Council (WTTC), the Statistical Office of the Slovak Republic, and databases of relevant ministries. Part of the primary data was collected through a questionnaire survey and structured interviews with representatives of towns and municipalities of the Novohrad region and inhabitants of the bordering region of Slovakia with Hungary and experts using the Delphi expertise method.

Secondary research data were gathered from accessible resources such as literature, academic publications, and monographs, scientific journals of WoS a SCOPUS.

The basic group consisted of 500 respondents from the border region. The statistical set of towns and villages of the Novohradský Region consisted of 140 addressed mayors of towns and other municipality authorities. The Delphi method by fifteen experts in tourism and cross-border cooperation was applied to the two-phase verification process of research results.
Primary and secondary resource data have been categorized, analyzed, and evaluated by standard scientific methods:

- Quantitative,

- Qualitative methods,

- Logical methods:

- abstraction and description,

- analysis and synthesis

- Mathematical statistics,

- Charts and diagrams,

- Comparative method,

- deduction and induction.

Mathematical statistics method of result evaluation included criteria of arithmetic mean, median, modus, variability, and dispersion.

Despite careful preparation authors of the research faced certain obstacles and limitations during implementation:

- lack of willingness from municipal authorities to fill an online questionnaire

- lack of skills regarding the use of electronic devices required for the online questionnaire

- respondents misunderstanding of questions and answers given in online questionnaire respondents

- incomplete nature of statistical data from international organizations, the Statistical Office of the Slovak Republic and relevant ministries

\section{RESULTS}

Given the limited capacity of the article, we present only some of the results as the most relevant to both quantitative and qualitative research on the relation to the set goal.

\subsection{Quantitative results}

The total contribution of tourism to Slovakia's GDP, including the wider effects of investments, the supply chain, and the impact on income in 2016, was 5.0 billion euro. In 2017, the share of tourism in the country's GDP was 6.3 and in 2018 there was a further increase to $6.4 \%$. Futureoriented, by 2027 , the total contribution of tourism to GDP should reach 7.1 billion euros. $(6.7 \%$ of GDP). An overview of the growth in the share of tourism in Slovakia's GDP for the years 2016 to 2018 with a view to 2027 is given in the graph in Figure 1. 
Data from WTTC indicate a ranking position of Slovakia among 170 countries of the world and particular neighboring countries included in evaluation in 2018. This result points out the deficiencies of the Slovak republic compared to neighboring countries excluding Poland and Ukraine.

10

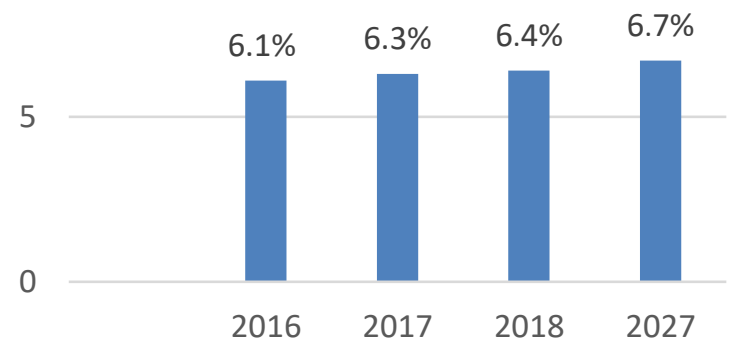

Fig. 1 share of the contribution of tourism to GDP growth in Slovakia in the period 2016 - 2018 in \%

Source: Authors' research
Table1 Ranking place of Slovakia in \% share of tourism on overall GDP in 2018

\begin{tabular}{|l|l|c|}
\hline Ranking & Country & $\begin{array}{c}\text { \% share of } \\
\text { tourism on GDP }\end{array}$ \\
\hline 1 & Macau & 72.2 \\
\hline 103 & Hungary & 8.5 \\
\hline 112 & Czech Republic & 7.8 \\
\hline 124 & Serbia & 6.9 \\
\hline 131 & Slovakia & 6.4 \\
\hline 146 & Ukraine & 5.4 \\
\hline 160 & Poland & 4.5 \\
\hline \multicolumn{2}{|c|}{ Source: (WTTC, 2019) }
\end{tabular}

Among all interesting quantitative indicators of the touristic impact on the economy of the country percentage share of tourism in the total employment rate in the Slovak Republic is mentioned.



Fig. 2 Share od employment rate in the tourism sector within the overall employment rate of Slovakia in 2007-2017 with further prospects into 2027.

Source: Authors' research

An interesting result of quantitative research is the analysis of the use of allocated EU funds for the development of tourism in the border regions of Slovakia and Hungary within the cross-border cooperation program INTERREG. Table 2 shows the insufficient effort of Slovak Republic to drawn the allocated funds for the development of tourism, as evidenced by the low percentage of these funds. The causes of this situation were examined through statistical surveys and structured interviews with competent public authorities.

The funds' absorption rate of Slovakia within the INTERREG III program after accession to the EU in 2004 received an even worse evaluation. Less 
than three years long preparation and implementation period resulted in a limited number of projects and their insufficient quality. None of seven submitted projects was approved as a consequence and Slovak republic did not draw any of 65.4 mil fund.

Table 2. Overview absorption of financial support from EU funds on touristic development within programs INTERREG VI. and INTERREG V. To date 31.03.2020

\begin{tabular}{|l|c|c|}
\hline \multicolumn{1}{|c|}{ Criteria } & $\begin{array}{c}\text { INTERREG } \\
\text { IV. } \\
\text { SK - HU } \\
2007-2013\end{array}$ & $\begin{array}{c}\text { INTERREG V. } \\
\text { SK - HU } \\
2014-2020\end{array}$ \\
\hline $\begin{array}{l}\text { Allocated } \\
\text { funds for the } \\
\text { development } \\
\text { of tourism }\end{array}$ & 175.6 mil. EUR & 65.2 mil. EUR \\
\hline $\begin{array}{l}\text { Number of } \\
\text { projects on } \\
\text { development } \\
\text { of tourism }\end{array}$ & 24 & 21 \\
\hline $\begin{array}{l}\text { Support } \\
\text { from ERDF }\end{array}$ & 23.4 mil. EUR & 26.1 mil. EUR \\
\hline $\begin{array}{l}\text { Share of } \\
\text { fund } \\
\text { absorption }\end{array}$ & 14\% & 39.9\% \\
\hline \multicolumn{2}{|c|}{ Source: Own elaboration based on } \\
(HUSK, 2020) and (n.d., 2019)
\end{tabular}

\subsection{Qualitative results}

The article illustrates the most relevant results of qualitative research.

The first results are drawn from the statistical survey of public satisfaction in the border area of the Slovak Republic and Hungary regarding the question of general awareness of the crossborder cooperation program. In a sample of 395 respondents, $76 \%$ of women and $33 \%$ of men, we found out that up to $48.4 \%$ knew nothing about the program, or rather nothing. Only $40 \%$ of respondents were aware of INTERREG activities. The other $11.7 \%$ could not comment on the question.

There was a general negative reply in more than $70 \%$ of the answers to question whether the public acknowledges poor accessibility (transport system) as a problem of cross-border cooperation. Details can be found in the graph in Figure 3.

Representatives of 5 cities and 145 municipalities of Novohrad region were inquired to provide the objective state of goals accomplishment of the INTERREG Slovakia - Hungary 2014-2020 (INTERREG V-A, 2020), cross-border cooperation program, to identify economic benefits and obstacles to the preparation and implementation of projects in the selected bordering regions with Hungary. An electronic questionnaire was correctly filled in by 52 respondents. The size structure of the towns and municipalities involved in the survey is shown in the graph in Figure 4.

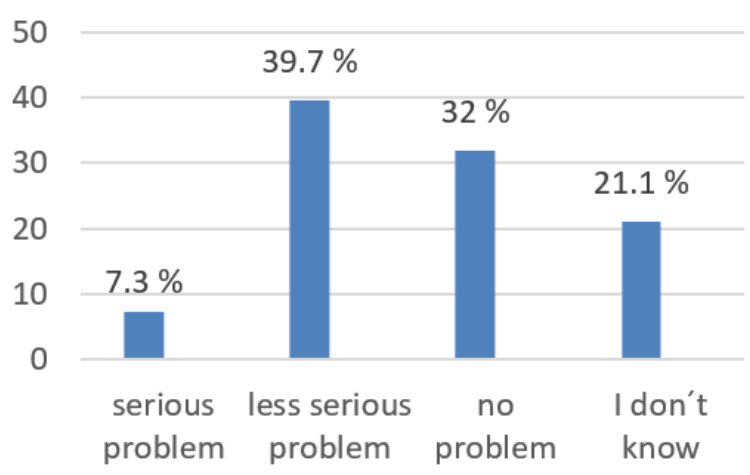

Fig. 3 Graph reflecting infrastructure obstacles of cooperation

Source: Authors' research

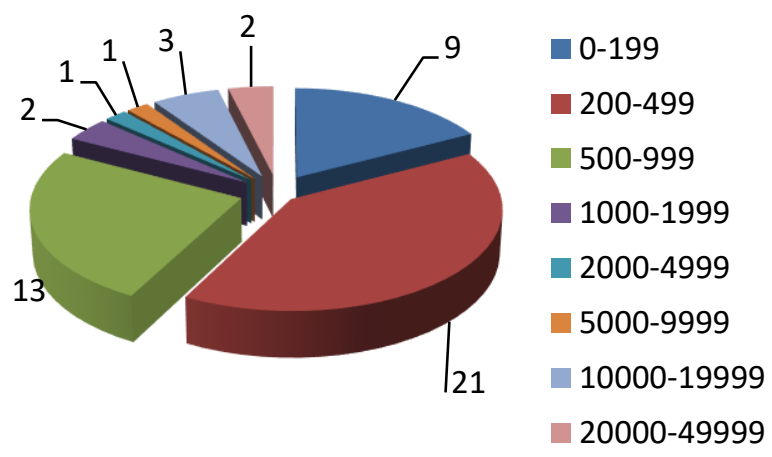

Fig. 4 Graph reflecting the size structure of towns and municipalities involved in the survey

Source: Authors' research

Question on whether and how much they had managed to improve the socio-economic situation after the implementation of cross-border cooperation projects aroused a rather pessimistic approach by respondents. More than 50\% of respondents suppose that the implementation of projects has not improved the socio-economic situation in the city/municipality in neither of the programming periods evaluated. In terms of identifying obstacles towards more efficient use of cross-border cooperation programs for tourism 
development and thus improvement of the socioeconomic situation in the municipality, respondents reported a lack of their funding to cofinance projects $(54.5 \%)$, the administrative burden of projects $(47.7 \%)$, lengthy process of project evaluation and implementation (40.0\%).

Quantitative research results were verified with the Delphi method. The verification process was carried out in form of an anonymous electronic questionnaire created by an expert in the sector of tourism and cross-border cooperation in two phases with the scope to achieve a consensus and unified conviction among the community of experts. The structure of experts can be found in Figure5.



- Employee of municipality

- Elected representative of municipality

- University teacher

- Project manager

Fig. 5 Professional structure of experts

- Parameters examined in the survey demonstrate significant level agreement in the opinions of experts on thirteen questions out of the total number of nineteen analyzed answers. The arithmetic mean of these responses ranged from 1.8667 to 2.933 . The median and modus ranged from 1 to 3 . The dispersion of responses ranged from 0.5156 to 1.956 and the standard deviation ranged from 0.422 to 1.2649 .

There was a disagreement among the experts on the six questions with increased arithmetic mean

of responses from 2.8667 to 3.333 , median and mode ranging from 3 to 4 , dispersion from 1.049 to 1.6889 , and standard deviation from 1.0242 to 1.2996 .

In compliance with standard methodology, the second round of the questionnaire was established to achieve a common agreement within the outstanding questions. The same criteria were applied to verify the credibility of responses. We were prone to use the $+10 \%$ rule to the median in case of a large dispersion or standard deviation. However, the results of the analysis of the responses reflected a significant consensus in the answers to the second round questions.

Based on the evidence stated above we might confirm and therefore verify subsequent hypotheses:

1. Cross-border Cooperation Program Hungary Slovakia $2014-2020$ is considered to be the most beneficial cross-border cooperation program between the Slovak Republic and Hungary for the development of tourism based on analysis data obtained from particular programs described in Table 2. So far, the program has supported 21 projects with a total amount of 26.1 mils. EUR.

Thus, given the reflected conclusion main hypothesis has been confirmed

2. The objectives of priorities of the cross-border cooperation programs met the expectation of the prior draft:

- Economic and social cohesiveness in border regions was achieved,

- Bordering regions have recorded a higher level of attention,

- Improvement of tourist management,

- Significant improvement of travel destination offer and eco-friendly touristic products

- The higher employment rate in the region

3. Objectives failed to succeed:

- To encourage the interest of eligible entities for small projects from the Small Projects Fund of the program

- 10 out of 15 experts report the failed attempt for a common promotion strategy of the border region between Slovakia and Hungary

- To encourage interest in cross-border cooperation projects among regional tourism organizations of particular districts (no project during both programming periods in question), even though partnership might have been beneficial in the preparation and implementation of projects, 
- according to experts the administrative burden of project preparation and implementation is an obstacle that diminishes the interest in cross-border cooperation projects to support the development of tourism. Up to $80 \%$ of experts have confirmed information

4. Obstacles emerged as a consequence of cross-bored cooperation programs reflected by experts:

- Cost of co-funding projects solely from the budget of the municipality,

- Complicated and lengthy system of reimbursement of eligible expenditure for the implementation of projects,

- The lengthy and administratively challenging process to verify the eligibility of expenditure.

- Lacking supervision interest of managing authorities of cross-border cooperation programs for methodological guidance and coordination of project preparation and implementation

- Methodological support of self-governing districts and regions reported a slightly better result of the evaluation

\section{PROPOSALS}

Suggestions for further activities developed under results from quantitative and qualitative research, including Delphi method:

1. Consider the already existing system of reimbursement of eligible expenditure with the possibility of converting it to an advance payment alternative following an example of projects from operational programs.

2. Revision of the administrative burden of project forms and proposal for simpler administrative forms.

3. To maintain to offer courses, seminars, and workshops for those interested in crossborder cooperation projects.

4. To provide applicants with a possibility to justify, or rather correct errors when verifying the eligibility of expenditure. The supreme audit office should not issue a decision not to award expenditure without prior written notification and justification of the applicant.

5. Consolidation of time horizons for verifying the accuracy of expenditures on both sides of Slovakia and Hungary.

\section{CONCLUSIONS}

The course of the research, but especially its results, clearly confirmed the importance and accuracy of the issue. The question of the benefits of cross-border cooperation programs for the development of tourism not only in Slovakia is crucial for the sustainable development of the socio-economic development of border regions. It holds significance for the sector of science and research, for competent state administration bodies and local government authorities, for interest groups of tourism, for business entities in tourism and their employees and last but not least for the population of the region confirming their interest by active participation in the statistical survey.

\section{WORKS CITED}

Bujdoso, Z., Lorant, D., Herneczky, A., \& Toth, G. (2007). The indicators of connection between tourism and regional competitiveness by the example of the Matravidek. Matarka, 4(1).

Gucik, M. (2011). Tourism. Politics and economy. Banska Bistrica: Touristic library, BB: Slovak - Swiss Tourism.

Gucik, M., \& al., e. (2012). Manazment cieloveho miesta cestovneho ruchu. Banská Bystrica: Univerzita Mateja Bela, Ekonomicka fakulta.

HUSK. (2020, 03 25). Hungary-Slovakia Cross-border Co-operation Programme 2007-2013. Retrieved from husk-cbc.eu: http://www.husk-cbc.eu/en/financed_projects/

INTERREG V-A. (2020, 03 25). INTERREG V-A Slovenská republika - Mad'arsko. Retrieved from INTERREG: http://www.skhu.eu/?lang=sk 
Kovac, M. (2016). Foreign economic activity of Ukraine for accession in EU: Experience of V4. Proceeding of Research projects of the Grant Agency of the VSEMvs (pp. 59-1). Bratislava: School of Economics and Management in Public Administration.

MoTC SR. (2020, 02 15.). Tourism. Retrieved from https://www.mindop.sk/ministerstvo-1/cestovnyruch-7/informacie/cestovny-ruch

MoTC SR. (2020, 02 20). Terminilogy of touristic terms. Retrieved from https://www.mindop.sk/ministerstvo-1/cestovny-ruch-7/informacie/cestovny-ruch

n.d. (2019, 11 20). Medical/welness tourism development in the world heritage caves of the Aggetelek and Slovak Karst. Retrieved from Interreg Slovakia-Hungary: http://www.skhu.eu/

Novacka, L'. (2011). Tourism and European Union. Praha: J.A.Komenského.

Palatkova, M. (2011). Global tourism (1st ed.). Praha: Grada.

Paunovic, I., \& Jovanovic, V. (2017). Implementation of Sustainable Tourism in the German Alps: A Case Study. Sustainability, 9(226), 1-15. doi:10.3390/su9020226

Sidak, M., Cibak, L., \& Hajnisova, E. (2020). Investment protection: determination of legal aspects with reflecting to the innovations to ensure sustainable growth of the Slovak Republic. Entrepreneurship and Sustainability Issues, 2350-2362.

Stoffelen, A., \& Vanneste, D. (2017). Tourism and cross-border regional development: insights in European contexts. European Planning Studies, 1013-1033.

Stoffelen, A., loannides, D., \& Vanneste, D. (2017). Obstacles to achieving cross-border tourism governance: A multi-scalar approach focusing on the German-Czech borderlands. Annals of Tourism Research(64), 126-138. doi:10.1016/j.annals.2017.03

UN WTO. (2017). Yearbook of Tourism Statistics Data 2013- 2017. http://statistics.unwto.org/publication/yearbook-tourism-statistics-2017-edition

UN WTO. (2020). Yearbook of Tourism Statistics Data 2014- 2020. Madrid: UN WTO. doi:10.18111/9789284421442

WTTC. (2019). Contribution of travel and tourism to GDP as a share of GDP. Retrieved from Knoema: https://knoema.com/atlas/topics/Tourism/Travel-and-Tourism-Total-Contribution-toGDP/Contribution-of-travel-and-tourism-to-GDP-percent-of-GDP?baseRegion=SK

\section{Acknowledgements}

This paper was supported by the project IGP 3/2019, which has received funding from the Grant Research Agency of the School of Economics and Management in Public Administration in Bratislava, of the Slovak Republic.

Received for publication: $\quad 31.03 .2020$

Revision received: $\quad 29.04 .2020$

Accepted for publication: $\quad 01.07 .2020$ 


\section{How to cite this article?}

Style - APA Sixth Edition:

Filip, S., Filipova, L., \& Reyevnyeva, O. (2020, July 15). European territorial cooperation as a factor of tourism development. (Z. Cekerevac, Ed.) MEST Journal, 8(2), 89-99. doi:10.12709/mest.08.08.02.09

Style - Chicago Sixteenth Edition:

Filip, Stanislav, L'ubica Filipova, and Olena Reyevnyeva. 2020. "European territorial cooperation as a factor of tourism development." Edited by Zoran Cekerevac. MEST Journal (MESTE) 8 (2): 8999. doi:10.12709/mest.08.08.02.09.

Style - GOST Name Sort:

Filip Stanislav, Filipova L'ubica and Reyevnyeva Olena European territorial cooperation as a factor of tourism development [Journal] // MEST Journal/ ed. Cekerevac Zoran. - Belgrade - Toronto : MESTE, July 15, 2020. - 2 : Vol. 8. - pp. 89-99.

Style - Harvard Anglia:

Filip, S., Filipova, L. \& Reyevnyeva, O., 2020. European territorial cooperation as a factor of tourism development. MEST Journal, 15 July, 8(2), pp. 89-99.

Style - ISO 690 Numerical Reference:

European territorial cooperation as a factor of tourism development. Filip, Stanislav, Filipova, L'ubica and Reyevnyeva, Olena. [ed.] Zoran Cekerevac. 2, Belgrade - Toronto : MESTE, July 15, 2020, MEST Journal, Vol. 8, pp. 89-99. 